\title{
Suvremeni pristupi i modeli zapošljavanja društvenib manjina u javnoj upravi
}

\author{
Tijana Vukojičić Tomic * \\ UDK $\quad 349.22: 35.08 .01$ \\ 331.5:35.08.01 \\ Review scientific paper / pregledni znanstveni rad \\ Received/primljeno: 21.3.2017. \\ Accepted / prihvaćeno: 11.9.2017.
}

\begin{abstract}
Zapošljavanje društvenih manjina u javnoj upravi predstavlja poseban pristup odabira i zapošljavanja javnih službenika, koji se sve više proučava. Naime, promjene u socio-demografskoj strukturi stanovništva i sve intenzivnije usložnjavanje suvremenih društava dovode do razvoja politika i čitavog niza mjera koje, strukturom ljudskih potencijala u javnoj upravi, nastoje odraziti složenost društvene okoline. Pored toga, posebni oblici zapošljavanja društvenih manjina razvijaju se u okviru međunarodnog antidiskriminacijskog prava još od sredine 1960-ih. Budući da u dostupnoj literaturi ne postoje ujednačena definicija, klasifikacija i nazivlje kojima bi bili obuhvaćeni svi aspekti takvog oblika zapošljavanja, u radu se razmatra mogućnost integracije praktičnih pristupa. Polazeći od dvaju temeljnih pristupa zapošljavanja društvenih manjina, afirmativnog pristupa i pristupa upravljanja različitošću, analiziraju se različiti modeli zapošljavanja u odabranim državama. $\mathrm{Na}$ temelju provedene analize, iznosi se prijedlog klasifikacije posebnih mjera zapošljavanja društvenih manjina u javnoj upravi na afirmativne metode $\mathrm{i}$ integrativne metode.
\end{abstract}

* Dr. sc. Tijana Vukojičić Tomić, predavačica na Katedri za upravnu znanost Pravnog fakulteta Sveučilišta u Zagrebu (lecturer at the Chair of Administrative Science, Faculty of Law, University of Zagreb, Croatia, e-mail: vukojicic.tijana@gmail.com) 
Ključne riječi: javna uprava, društvene manjine, zapošljavanje društvenih manjina, afirmativni pristup, upravljanje različitošću

\section{Uvod}

Postupak $^{1}$ odabira i zapošljavanja upravnog osoblja spada među najvažnija područja upravljanja ljudskim potencijalima, jer organizacijska učinkovitost i izvršenje ovise o kvaliteti javnih službenika (Marčetić, 2007, str. 187). Privlačenje širokog kruga potencijalnih kandidata za rad u upravi povećava broj kvalificiranih, sposobnih i kvalitetnih ljudi koji svojim znanjem, vještinama i motiviranošću mogu pridonijeti uspješnijem radu uprave. ${ }^{2}$ Stahl (1956, str. 59) posebno ističe dva međusobno povezana razloga zbog kojih se tema odabira i zapošljavanja javnih službenika nameće kao središnja tema upravljanja ljudskim potencijalima uopće. Prvo, odabir upravnog osoblja, koji je u skladu s jasnom i usklađenom personalnom politikom, može osigurati odabir najboljih kandidata za rad u javnoj upravi. Drugo, temeljno razlikovanje između postupka odabira kandidata za posao u javnoj upravi i posao u privatnom sektoru proizlazi iz primjene merit načela uspostavljanjem specifičnog sustava odabira i zapošljavanja službenika. Za razliku od privatnog sektora, gdje je postupak zapošljavanja gotovo nevidljiv javnosti, odabir i zapošljavanje javnih službenika odvija se u okviru kompleksnih proceduralnih zahtjeva, mora biti prihvatljiv javnosti te je izložen stalnom nadzoru relevantne okoline (Hays \& Sowa, 2005, str. 99).

1 Rad je nastao u okviru znanstvenoistraživačkog projekta za 2015. godinu Pravnog fakulteta Sveučilišta u Zagrebu pod nazivom Novi brvatski pravni sustav.

${ }^{2}$ Razmatrajući najprikladnije načine privlačenja i zadržavanja najkvalitetnijih ljudi u upravi, Koprić (2009, str. 9) razlikuje kratkoročne i dugoročne mjere, koje je potrebno poduzeti. Kratkoročne mjere uključuju prevenciju diskriminacije, uklanjanje patronaže i političkog upletanja u proces zapošljavanja, unapređenje pravne regulative, nagrađivanje službenika za dobre rezultate u poslu, jačanje odnosa s građanima i usvajanje dobrih praksi upravljanja ljudskim potencijalima. Dugoročne mjere odnose se na poticanje stvaranja boljeg javnog imidža uprave, jačanje faktora koji mogu dodatno motivirati zaposlenike, poticanje profesionalno-proaktivnog stava službenika i kohezivne organizacijske kulture, jačanje veza s akademskom zajednicom i organizaciju posebnih edukacijskih sadržaja i programa za službenike te isticanje prednosti koje donosi zapošljavanje u javnoj upravi. U nastojanju da privuku talentirane kandidate, javne organizacije moraju nastupiti promišljeno, energično i inovativno (Hays \& Sowa, 2005, str. 106). 
Pitanje odabira javnih službenika u novije se doba veže uz pitanje povećanja složenosti društva, naročito socio-demografske, i s tim u vezi upravljanja različitošću (diversity management) u javnoj upravi. To je jedna od glavnih tema ${ }^{3}$ s obzirom na odluke o odabiru ljudskih potencijala, jer povećana heterogenost okoline tržišta rada - kao što je starenje stanovništva, rast obrazovane radne snage i zapošljavanje sve većeg broja žena - pred javnu upravu postavlja zahtjev učinkovitijeg upravljanja različitošću. Različitost se u kontekstu društva tradicionalno odnosi na rasnu, nacionalnu i rodnu pripadnost pojedinaca ili grupa, ali prema suvremenom shvaćanju ona obuhvaća dodatne kategorije različitosti pojedinaca, poput dobi, invaliditeta, socijalnog statusa i vjeroispovijedi (Guy \& Newman, 2005, str. 143).

Suvremena literatura o upravljanju ljudskim potencijalima u javnoj upravi posvećuje sve veću pažnju upravljanju različitošću i reprezentativnom zapošljavanju, a razlozi pojačanog interesa znanstvenika i praktičara za tu temu jesu: socio-demografski razvoj, nove ideje o političkoj reprezentaciji, kulturološke promjene i promjene u stavovima te socio-ekonomske promjene (Peters et al., 2013, str. 12-14). Socio-demografski razvoj današnjih europskih država, koje su tradicionalno bile pretežito nacionalno homogene $\mathrm{dr}$ žave (»nacionalne države «), ${ }^{4}$ pokazuje trend sve većoj kulturnoj raznolikosti društava, i to primarno kao rezultat europske integracije, geografske mobilnosti na zajedničkom europskom tržištu, ekonomske globalizacije i suvremenih migracijskih trendova. Zbog takvih promjena države moraju mijenjati i prilagođavati svoje javne politike kako bi zadovoljile specifične interese i potrebe novih manjinskih skupina, što uključuje i politiku zapošljavanja.

U okviru općeg diskursa propulzivne »politike identiteta« odnosno »politike priznanja«, integracija društvenih manjina ${ }^{5}$ nije samo pitanje funkci-

${ }^{3}$ Uz pitanje upravljanja raznolikošću, suvremena literatura o upravljanju ljudskim potencijalima ističe drugačije potrebe organizacije dostupnih ljudskih potencijala u odnosu prema tradicionalnom vezanju odabira kandidata uz fiksne zahtjeve određenog posla. Također, upućuje se na potrebu uspostavljanja uske dvosmjerne veze između poslovnog planiranja, kompetitivne strategije i planiranja ljudskih potencijala u javnoj upravi. Više Marčetić, 2007, str. 192-193.

${ }^{4}$ Raspravljajući o kulturnoj različitosti suvremenih društva, odnosno multikulturalizmu, Mesić (2006, str. 69) ističe da u njegovu demografsko-deskriptivnom određenju sporno postaje pitanje »priznavanja« društva kao multikulturalnog, jer to znači da bi takva društva morala odbaciti duboko usađenu predodžbu o nacionalnoj državi kao kulturno homogenoj zajednici, ili barem zajednici koja teži takvom cilju kao svom idealu.

${ }^{5}$ Mnogobrojne su teorijske definicije pojma manjina ili manjinskih skupina. No, kako se njima ne mogu obuhvatiti svi oblici i sva obilježja različitosti čiji se krug s vremenom širi, u literaturi se uglavnom navode karakteristična obilježja manjinskih skupina. Wagley i Harris (1958, prema: Henderson \& Olasiji, 1995, str. 5-6) identificiraju pet takvih obilježja: po- 
onalne nužnosti ili politički oportunog ponašanja, već priznanje manjinskih prava per se. Uz politički smisao priznanja pojedinaca u njihovoj različitosti, raste pritisak na upravne organizacije da se, kao provedbeni mehanizam politike, otvore prema pripadnicima manjinskih skupina i na taj način simboliziraju stvarnu integraciju manjina u društvu. Zapošljavanje različitih segmenata društva u javnoj upravi može se sagledati i iz perspektive zahtjeva stanovništva, heterogenog po svom demografskom sastavu, za većom odgovornosti i odazivnosti države, naročito u vrijeme pada povjerenja i otuđenosti građana od institucija političke vlasti. Postavlja se pitanje »koga zapravo reprezentira upravno osoblje« (Peters et al., 2013, str. 12-14). Socio-ekonomske promjene također utječu na donošenje nacionalnih programa i mjera zapošljavanja. Kako se resursi za raspodjelu socijalnih davanja smanjuju, tako politika "priznanja« postaje instrument kojim se održava socijalni mir, a reprezentativno zapošljavanje predstavlja jedan od instrumenata kojim se zadovoljavaju interesi različitih manjinskih skupina u društvu.

Osim toga, postavlja se pitanje svrhe reprezentativnog zapošljavanja u javnoj upravi kao odgovora na sve veće demografske i druge oblike složenosti društva. Zapošljavanje javnih službenika koje je u demografsko-socijalnom smislu heterogeno može pridonijeti uspješnosti organizacije, jer se na taj način organizacija bolje prilagođava okolišnoj raznovrsnosti. U uvjetima kretanja prema sve većoj složenosti okoline postoji stalni pritisak za diferenciranjem sustava javne uprave, odnosno njegova uspješnost $\mathrm{u}$ odnosu s okolinom ovisi o njegovoj sposobnosti da u sebi odrazi složenost relevantne okoline (Koprić, 1999, str. 126). Upravno osoblje koje je po svom demografsko-socijalnom sastavu raznovrsno može se bolje prilagoditi složenoj okolini i zahtjevima koji dolaze iz takve okoline u odnosu na homogenu radnu snagu (Guy \& Newman, 2005; Meier et al., 1999).

Druga se svrha zapošljavanja manjina veže uz pitanje pravednosti i jednakih mogućnosti u zapošljavanju javnih službenika. U vrijeme povećane složenosti ili »različitosti« u društvima, dolazi naročito do izražaja simbolička uloga javne uprave kao poslodavca koji promiče takve vrijednosti

vijesno nejednak položaj odnosno izloženost nepravednom postupanju, članova manjinske skupine, uočljive fizičke ili kulturne karakteristike koje ih razlikuju od ostatka stanovništva, pripadnost grupi koja se ne temelji na svjesnoj odluci pojedinca, naglašena pojava sklapanja braka među članovima grupe i postojanje svijesti o manjinskom statusu u odnosu prema drugima. Uzevši u obzir navedena karakteristična obilježja, društvene manjine definiraju se kao pojedinci ili skupine u društvu koji se po svojim pripisanim i stečenim obilježjima razlikuju od drugih pojedinaca ili skupina u društvu i koji su povezani kolektivnom željom za očuvanjem tih obilježja i stjecanjem jednakih prava i sloboda u odnosu prema drugim pojedincima ili skupinama u društvu zbog svog slabijeg društvenog položaja. 
(Frederickson, 2010; Peters, 2013). Tema društvene pravednosti kao vrijednosti kojoj javna uprava u svom radu treba biti posebno predana prvi se put naglašava i dublje analizira u okviru upravne doktrine nove javne uprave. Njezini zagovornici smatraju da društvena pravednost obuhvaća niz vrijednosnih orijentacija, odabira optimalnog organizacijskog dizajna i tipa upravljanja koji, uz tradicionalne vrijednosti efikasnosti i ekonomičnosti, može pridonijeti otklanjanju društvenih nejednakosti. Frederickson (2010, str. 101), kao jedan od istaknutijih predstavnika te upravne doktrine, navodi da je 1970-ih godina u SAD-u postignut značajan napredak u pitanju društvene pravednosti u radu javne uprave donošenjem programa jednakih mogućnosti u zapošljavanju. Riječ je o poduzimanju posebnih mjera u zapošljavanju manjina koje mogu ići u dva smjera: uklanjanje ili ublažavanje učinaka diskriminatornih praksi u području zapošljavanja i/ili integracija različitosti u organizaciji. Odabir određenog tipa posebne mjere zapošljavanja manjina ovisi o razlozima za poduzimanje takvih mjera i o cilju koji se želi postići, a sve to u okviru općih karakteristika upravne tradicije koje pretežu u pojedinom društvu.

Budući da u dostupnoj literaturi ne postoji klasifikacija metoda zapošljavanja pripadnika manjinskih skupina, u radu se analiziraju odabrani modeli zapošljavanja pripadnika manjina u javnoj upravi u različitim zemljama. Takav pristup omogućuje njihovu sintezu i prijedlog klasifikacije mjera u osnovne modele.

\section{Temeljni pristupi u zapošljavanju društvenih manjina kao rezultat različitih polazišta - suzbijanje diskriminacije i upravljanje različitošću}

Zapošljavanje u javnoj upravi ima više značenja i može se promatrati s aspekta nekoliko osnovnih svrha (Peters et al., 2013, str. 6-7). S aspekta organizacijske svrhe, ljude u upravi povezuje se sa zadacima i naročito se ističe pitanje njihove uspješnosti i radne učinkovitosti. U samom je središtu promatranja način na koji se kandidati za rad u upravi odabiru i zapošljavaju (primjena merit načela ili sustav patronaže), vrijednosti koje njeguju, sociodemografsko porijeklo i osnovne karijerne orijentacije javnih službenika, ali $\mathrm{i}$ institucionalno okruženje u kojem službenici rade. S makroekonomskog aspekta promatra se položaj javne uprave kao poslodavca u odnosu na nacionalno tržište rada i zapošljavanja, s obzirom na to da javna uprava nerijetko zapošljava značajan dio radno aktivnog stanovništva. Zbog toga zapošljava- 
nje u javnoj upravi može imati velik utjecaj na trend razvoja plaća radnika na tržištu rada i stopu nezaposlenosti, a javna uprava ulogu poslodavca koji predstavlja model (model employer) drugim sektorima, naročito kad je riječ o provedbi načela jednakih mogućnosti u zapošljavanju. Politička se svrha očituje primarno kroz proces donošenja političkih odluka u kojem javna uprava ima važnu ulogu, posebno kao mjesto na kojem se kanaliziraju interesi različitih društvenih skupina. Zapošljavanje u javnoj upravi ima i socio-kulturnu ulogu posrednika u procesu društvene pokretljivosti (mobilnosti) pojedinaca i skupina, kako njihove socio-ekonomske mobilnosti tako i socijalizacije unutar demokratskih političkih sustava. Prilikom analize zapošljavanja i razrade metoda odabira javnih službenika treba uzeti u obzir sve navedene svrhe, a naročito specifične zahtjeve kojima ono treba udovoljiti s obzirom na javni karakter poslova upravnih organizacija.

Promjene u demografskoj i socijalnoj strukturi stanovništva suvremenih društava, u kombinaciji s proširenjem kruga ljudskih prava i interesa što ih građani u tom pogledu izražavaju, odražavaju se i na politike upravljanja ljudskim potencijalima. S jedne strane,»kulturna identitetna različitost « (Mesić, 2006, str. 53) postaje neosporiva društvena činjenica, manje ili više izražena u pojedinim zemljama. Na nju utječu procesi poput etničkog usložnjavanja društva zbog sve intenzivnijih migracija, starenja radne snage, porasta obrazovne razine stanovništva, naročito žena, ekonomskih kriza i s njima povezane neravnomjerne raspodjele bogatstva, posljedica ratnih i drugih oblika oružanih sukoba (npr. demografske promjene, porast broja osoba s invaliditetom) i sl. S druge strane, potaknuto nastojanjima građana da ostvare svoje interese i sudjeluju u donošenju kolektivnih odluka širi se krug legitimnih interesa, tj. društveno prihvaćenih i pravno reguliranih interesa što ih građani izražavaju i nastoje ostvariti (Pusić, 2005, str. 257). Ta se tendencija odražava u sve čvršćem normativnom utemeljenju načela jednakosti i sve većoj toleranciji prema različitostima među ljudima koje proizlaze iz njihovih osobnih svojstava i vrijednosnih opredjeljenja.

U osnovi je svih pristupa zapošljavanja manjina pitanje različitosti, pa je potrebno razlučiti koji su njezini izvori i dimenzije. Bahtijarević-Šiber (2014, str. 364) govori o primarnim i sekundarnim dimenzijama različitosti ovisno o tome jesu li naslijeđene i nepromjenjive/teže promjenjive ili stečene tijekom života i promjenjive. Primarne dimenzije različitosti, kao što su spol, dob, etnička pripadnost i rasa oblikuju sliku koju pojedinac ima o sebi i njegov pogled na svijet pa zbog toga znatno utječu na njegovo ponašanje. Nešto slabiji, ali ipak značajan utjecaj na samoodređenje osobe i na to kako je doživljavaju drugi imaju sekundarne dimenzije različitosti (npr. obrazovanje, prihodi, radno iskustvo, religija). Karakterizira ih promjenjivost jer 
se postupno stječu tijekom života. Gardenswartz i Rowe $(2003)^{6}$ dodaju i treću dimenziju koju nazivaju organizacijskom dimenzijom. Ta dimenzija određena je položajem i ulogom pojedinca u organizaciji, a obuhvaća funkciju koju pojedinac obnaša u organizaciji, mjesto rada, odjel, trajanje zaposlenja, sadržaj rada i sklonost prema sindikalnom udruživanju.

Mesić (2006, str. 53) polazi od kulturne identitetne ${ }^{7}$ različitosti (multikulturalizma) suvremenih društava i sistematizira ih u tri tipa grupnih formacija. U prvoj su grupi kulturno derivirane, tj. etnokulturne različitosti, $\mathrm{u}$ koje spadaju indigeni narodi, nacionalne manjine, etničke grupe i useljenici. U drugoj su različitosti temeljene na spolnom ili rodnom identitetu (žene, homoseksualci, lezbijke). Treće su temeljene na posebnim fizičkim obilježjima (invalidi, stariji).

Konceptualizacije različitosti polaze od pojedinčeva pojma o sebi i znanja o pripadnosti socijalnoj grupi ili grupama te vrijednostima koje se vežu uz to članstvo. No, kakvu to važnost ima za upravljanje ljudskim potencijalima? Najopćenitije rečeno, različitost u radnom okruženju znači ljudske potencijale sačinjene od dviju ili više grupa zaposlenika različite rasne, nacionalne, rodne, kulturne i vjerske pripadnosti te drugih obilježja poput dobi ili invaliditeta (Dessler, 2005, str. 55). Dominantne promjene u strukturi ljudskih potencijala odnose se na sve veće sudjelovanje žena i pripadnika različitih etničkih skupina, a uz to, starenje postaje vrlo izraženo obilježje ljudskih potencijala u svim zemljama (Bahtijarević-Šiber, 2014, str. 361).

S obzirom na brze i vrlo značajne demografske promjene na tržištu rada, ${ }^{8}$ pitanje demografskog sastava ljudskih potencijala i novi pristupi razli-

\footnotetext{
${ }^{6}$ Prikaz dimenzija različitosti dostupan na web stranici http://www.gardenswartzrowe.com/why-g-r.

${ }^{7}$ Identitet je, prema Mesiću (2006, str. 281), »veza koja drži neki kolektiv na oku$\mathrm{pu}$, a isključuje druge koji ne ispunjavaju kriterije pripadanja«. Shvaća se vrlo općenito kao »spona« među pojedincima koji se tako identificiraju. Appiah (1994, prema Mesić, 2006) upozorava na dvije dimenzije identiteta: kolektivnu i personalnu. Kolektivna derivira iz grupnih obilježja kao što su rod, vjera, etnicitet, rasa ili seksualnost, a personalna se sastoji od moralno važnih osobitosti kao što su inteligencija, šarm, duhovitost, lakomost i dr. Na dualizam pojma identiteta upućuje i Erikson (1959, prema Čačić-Kumpes, 2004, str. 146). On istovremeno znači nepromjenjivost osnove vlastitog bića i njegova kontinuiteta u vremenu, ali i društveni karakter tog identiteta koji se očituje u činjenici da drugi primjećuju sličnost osobe samoj sebi i kontinuitet njezina bića. A identitet se »definira i potvrđuje u razlici« (Bourdieu, 1979, prema Čačić-Kumpes, 2004, str. 146).

${ }^{8}$ Dessler (2005, str. 466) navodi neke trendove u demografskom sastavu tržišta rada na primjeru Europske unije i Velike Britanije. Iako podaci Eurostata pokazuju da će ukupan broj stanovnika 15 država članica Europske unije (prije novih proširenja) biti stabilan
} 
čitosti postaju središnje teme upravljanja ljudskim potencijalima uopće (Millmore et al., 2007, str. 466-468). Novi pristupi idu za tim da maksimiraju ljudske potencijale koji proizlaze iz različitosti, ali i da istovremeno otklone tj. ublaže prepreke kao što su predrasude i podjele koje mogu otežati dobro funkcioniranje raznolikih ljudskih potencijala. Kako bi se to postiglo, poduzimaju se mjere koje se, s obzirom na razlike u temeljnom polazištu na kojem djeluju, svrsi koja se želi postići, stupnju centralizacije odlučivanja i načinu mjerenja uspjeha mogu klasificirati u dvije osnovne skupine: afirmativni pristup i pristup upravljanja različitošću. ${ }^{9}$

Afirmativni pristup polazi od problema diskriminacije i ispravljanja posljedica prijašnje diskriminacije. Radi se o donošenju niza mjera usmjerenih na poboljšanje položaja onih grupa u društvu koje su prethodno bile isključene ili slabije zastupljene (Selden, 1997, str. 38), a koje konkretno trebaju pridonijeti jednakim mogućnostima pri zapošljavanju u javnom i privatnom sektoru. U okviru tog pristupa različitost među ljudima operacionalizira se kroz aspekt nejednakog položaja u društvu različitih društvenih skupina. $\mathrm{Na}$ razini provedbe moguće je razlikovati afirmativnu akciju i jednake mogućnosti u zapošljavanju koje se uglavnom pojavljuju kao komplementarni pristupi, a povezuje ih usmjerenost na problem diskriminacije.

Iako se vrlo često koriste kako bi se objasnile iste pojave, među njima postoje razlike (Riccucci, 2005; Dessler, 2005). Jednake mogućnosti u zapošljavanju naglasak stavljaju na zabranu diskriminacije i uglavnom obuhvaćaju antidiskriminacijsko zakonodavstvo. Kao pristup, široko je prihvaćen, jer se doživljava kao sredstvo prevencije diskriminacije na radnom mjestu na osnovi rase, vjerske pripadnosti, spola, nacionalnosti, dobi i fizičke i psihičke sposobnosti pojedinaca. Temelji se na pretpostavci jednakih mogućnosti i odgovara »tradicionalnoj personalnoj funkciji koja zaposlene promatra kao kolektiv« (Bahtijarević-Šiber, 2014, str. 369).

u idućih 25 godina, struktura stanovništva i njihova demografska obilježja značajno će se promijeniti. Posebno se to odnosi na dob radno sposobnog stanovništva (16-59) koja će biti u padu sa 228 milijuna 2005. godine na 203 milijuna do 2030., dok će broj osoba starijih od 60 godina narasti sa 86 milijuna na 123 milijuna, što predstavlja rast više od 40 posto. Eurostat predviđa da će te demografske promjene imati znatan utjecaj na sastav radne snage u Europskoj uniji.

${ }^{9} \mathrm{Uz}$ već navedeni problem nepostojanja sustavno razrađene klasifikacije pristupa u zapošljavanju društvenih manjina u javnoj upravi, raznovrsnost modela zapošljavanja društvenih manjina nameće pitanje njihove prilagođenosti okolnostima koje prevladavaju u pojedinoj zemlji kao preduvjeta njihove optimalne primjene i postizanja željenih rezultata. Stoga se najprije identificira širok spektar mjera koje se provode u odabranim zemljama kako bi se na taj način mogle klasificirati u neke osnovne skupine i time dobiti polazišne pristupe zapošljavanja društvenih manjina u javnoj upravi. 
S druge strane, afirmativna akcija obuhvaća proaktivne mjere tijela javne vlasti u smjeru ispravljanja posljedica prijašnje diskriminacije koje djeluju na povećanje raznolikosti radne snage, npr. u pogledu rase, nacionalnosti, spola i psihofizičke sposobnosti pojedinaca. Donošenje takvih mjera treba rezultirati mjerljivim godišnjim rezultatima i u konačnici korigiranjem postojeće strukture zaposlenih u odnosu na dimenzije diskriminacije koje se utvrđuju zakonima ili drugim aktima koje donose tijela središnje vlasti. Afirmativna akcija je zbog toga je podijelila stručnu i širu javnost na zagovornike i oštre kritičare, a osnovni se prigovori odnose na kršenje načela jednakosti svih građana, donošenja odluka o zapošljavanju na temelju pripadnosti skupini, a ne individualnih sposobnosti i stavljanje u povoljniji položaj pripadnika pojedinih društvenih skupina. ${ }^{10}$

Posebne mjere zapošljavanja u okviru afirmativnog pristupa najčešće se donose na središnjoj razini i mogu biti neobvezujuće i obvezujuće naravi. One se u okviru pristupa jednakih mogućnosti pri zapošljavanju ne formuliraju pravno kao obveza adresata antidiskriminacijske zaštite već kao njegovo pravo (Potočnjak \& Grgić, 2014b, str. 172). Za razliku od toga, afirmativna akcija želi neutralizirati učinke prethodne diskriminacije i stoga obvezuje organizacije u njihovu provođenju. Primjer za to su kvote ili brojčano iskazani ciljevi zapošljavanja kojima se organizacije obvezuje na pojačano zapošljavanje pripadnika manjinskih skupina kako bi se njihov položaj izjednačio s drugim pripadnicima društva. Zbog toga su takve mjere vrlo često privremene naravi, odnosno određuje se njihovo privremeno djelovanje koje se iscrpljuje postizanjem stvarne jednakosti. ${ }^{11}$

${ }^{10}$ Iako se prije u literaturi izraz pozitivna diskriminacija, kojim se označuje pravom dopušteno pogodovanje određenih osoba ili skupina osoba u odnosu na druge osobe ili skupine osoba u usporedivoj situaciji, često dovodi u vezu s afirmativnim pristupom u zapošljavanju, u novije se vrijeme izbjegava njegovo korištenje (Potočnjak \& Grgić, 2014a, str. 9). Diskriminacija predstavlja nezakonito postupanje, pa s obzirom na to da se o diskriminaciji govori samo kad je riječ o razlikovanju koje je pravom zabranjeno (nedopušteno), sintagma »pozitivna diskriminacija « predstavlja contradictio in terminis. Danas se za označivanje situacije u kojoj je pravom dopušteno pogodovanje određenih osoba ili skupina osoba rašireno koristi pojam posebne ili pozitivne mjere.

11 Potočnjak i Grgić (2014b, str. 173-174) naglašavaju da pozitivnim (posebnim) mjerama ne može biti shvaćeno svako pogodovanje društvenim skupinama koje su u nepovoljnijem položaju. Tako npr. čl. 9/2. Zakona o suzbijanju diskriminacije (NN 85/08, 112/12) određuje da te mjere moraju biti privremene, nužne i prikladne za ostvarivanje stvarne jednakosti društvenih skupina koje su u nepovoljnijem položaju. Mjere koje ne zadovoljavaju test razmjernosti predstavljaju izravnu ili neizravnu diskriminaciju, što ovisi o tome na koji način sud pristupa primjeni testa razmjernosti. Iz prakse Suda EU-a, pozitivne mjere tumače se restriktivno, kao uska iznimka od načela zabrane diskriminacije, dok hrvatska ustavnosudska praksa, prema mišljenju autora, testu razmjernosti pristupa nešto ekstenzivnije. 
Prema Tintiću (1972, str. 91; 105), riječ je o zakonskoj obvezi organizacija da zaposle određene kategorije osoba koja postoji onda kad se steknu određene objektivne i subjektivne pretpostavke propisane zakonom. Ostvaruje se kao pravo prednosti (prioriteta) u zapošljavanju koje se ne smatra diskriminacijom na štetu drugih kandidata ako su kriteriji prednosti utvrđeni pravnim poretkom. Pri popunjavanju slobodnih radnih mjesta organizacija ima zakonsku obvezu da prvenstveno primi određenog kandidata koji ostvaruje pravo prednosti ${ }^{12}$ pri zapošljavanju, iako svi kandidati jednako ispunjavaju uvjete propisane za primanje na rad na određenom radnom mjestu (pravo prednosti pod jednakim uvjetima). Iz takvog pravnog uređenja posebnih mjera proizlazi i način mjerenja njihova uspjeha. Ponajprije se koriste pravni kriteriji i nadzire se poštovanje tih kriterija uobličenih u formalizirana pravila. Afirmativna akcija dodatno provjerava usklađenost strukture zaposlenih sa strukturom radne snage uzimajući u obzir dimenzije različitosti koje su utvrđene pravnim poretkom.

Upravljanje različitošću noviji je pristup zapošljavanju manjina razvijen krajem 1980-ih godina u SAD-u. Zbog brzih i značajnih promjena u suvremenim organizacijama i njihovoj okolini, upravljanje različitošću postaje bitan strateški zahtjev ${ }^{13}$ upravljanja ljudskim potencijalima (BahtijarevićŠiber, 2014, str. 361). Naime, donošenje mjera kojima je cilj poboljšanje položaja pojedinih društvenih skupina u okviru afirmativnog pristupa ima neke manjkavosti. Prije svega to se odnosi na činjenicu da ne pridonosi uspostavljanju čvrstih veza među ljudima u organizaciji - integraciji te organizacijskoj uspješnosti (Dessler, 2005, str. 56). Pristup upravljanja različitošću premješta obrasce upravljanja ljudskim potencijalima s konvencionalnog zakonodavnog aspekta jednakih mogućnosti u zapošljavanju na strategiju uvažavanja razlika kao što su spol, dob, socijalno porijeklo, invaliditet, osobnost, nacionalno porijeklo i stil rada (Kandola \& Fullerton, 1994, prema: Millmore et al., 2007, str. 470). Imperativ konkurentnosti današnjih tržišta pretvara ga u strateški pristup koji u prvom redu može osigurati osvajanje novih potrošača i tržišta, ali isto tako i privlačenje ta-

12 Prioritet (prednost) može biti neposredan i posredan (Tintić, 1972, str. 105). Ako je neposredan, organizacija je dužna zaposliti (najčešće ponovo zaposliti) određenog identificiranog kandidata. Ako je posredan, organizacija je dužna prvenstveno zaposliti kandidata iz određene kategorije radnika, najčešće one koja je označena u zakonu.

13 Strateškim se smatra zato što počiva na zdravom poslovnom smislu i logici jer otvara širu bazu potrošača, privlači najbolje talente, a ujedno jača važne etičke aspekte organizacije (Bahtijarević-Šiber, 2014, str. 363). Smatra se i važnom strateškom tehnologijom i strateškim integratorom za menadžere ljudskih potencijala, kao i strateškim imperativom upravljanja ljudskim potencijalima. 
lentiranih i kompetentnih kandidata, pa se zato sve više promatra kao dobra poslovna strategija (Bahtijarević-Šiber, 2014, str. 362).

Pristup upravljanja različitošću polazi od drugačijih premisa i ima drugačije ciljeve nego afirmativni pristup. Osnovna je ideja da korištenje razlikama u upravljanju ljudskim potencijalima može stvoriti produktivnu okolinu u kojoj se potencijali zaposlenika potpuno iskorištavaju, a oni se pritom osjećaju cijenjenima, što doprinosi postizanju organizacijskih ciljeva među kojima su korištenje različitostima za podizanje kreativnosti i inovacija, zadovoljavanje potreba sve različitijih potrošača i otvaranje novih prilika za razvoj uz pomoć novih tržišta i potrošača, podizanje kvalitete i organizacijske uspješnosti, smanjivanje troškova nastalih zbog diskriminacije i uznemiravanja itd. (Bahtijarević-Šiber, 2014, str. 363).

Neki autori smatraju da je pristup upravljanja različitošću pokušaj spašavanja afirmativne akcije postavljanjem na drugačije, poslovno orijentirane temelje (Lynch, 2005, prema: Van Gool, 2015, str. 176-177). Naglasak na društvenoj pravednosti u okviru afirmativne akcije ustupio je mjesto poslovnoj uspješnosti kroz osnovnu ideju da će one organizacije koje »ozbiljno shvate različitost - zapošljavaju manjine, stvaraju inkluzivnu organizacijsku kulturu i prepoznaju, uvažaju, poštuju i slave različitost - biti nagrađene većom djelotvornošću i inovativnošću u radu svojih zaposlenika i tako postići veću organizacijsku uspješnost.

S obzirom na to da je upravljanje različitošću vrlo zahtjevan program upravljanja ljudskim potencijalima, Bahtijarević-Šiber (2014, str. 377) iznosi nekoliko kategorija aktivnosti koje su identificirane kao ključne za svaki program upravljanja različitošću. Organizacija prvenstveno mora osigurati jako vodstvo koje prihvaća ideje različitosti i uvođenje promjena u organizaciji. Potrebno je procijeniti situaciju i identificirati probleme vezane uz različitost npr. mjereći jednake mogućnosti u zapošljavanju ili istraživanjem stavova zaposlenika. Zaposlenicima treba osigurati obučavanje i obrazovanje za različitost, a njih kombinirati s drugim mjerama radi mijenjanja organizacijske kulture i sustava menadžmenta. Zadnja i ključna aktivnost odnosi se na stalno praćenje primjene i rezultata programa mjerenjem promjene kulture i postizanja poslovnih ciljeva, primjerice praćenjem promjena i poboljšavanja u stavovima zaposlenika prema različitosti. Potonje upućuje na drugačiji način mjerenja uspješnosti programa u odnosu na afirmativni pristup koji težište stavlja na provjeru djelovanja prema pravnim pravilima i uspoređivanju strukture zaposlenih sa strukturom radno sposobnog stanovništva po različitim socio-demografskim osnovama.

U osnovi se razlike između pristupa mogu svesti na nekoliko aspekata. Pristup upravljanja različitošću usmjeren je na maksimiranje potencijala svih 
zaposlenika i uspješnost organizacije pa je zato trajnog karaktera, a dimenzije različitosti širi na sve karakteristike po kojima se ljudi razlikuju. Afirmativni pristup polazi od pravno utvrđenih dimenzija diskriminacije i usmjeren je na problem diskriminacije i ispravljanje posljedica diskriminacije pa je najčešće ograničenog trajanja. Iniciranje programa u prvom je slučaju dobrovoljno i utvrđuju ga same organizacije, a u drugom zakonski uvjetovano i vrlo često obvezno. Upravljanje različitošću zahtijeva promjene u vrijednostima, organizacijskoj kulturi i upravljanju pa se shodno tome uspjeh programa mjeri prema promjeni kulture, ali i postizanju poslovnih ciljeva, dok afirmativni pristup inzistira na poštovanju pravnih pravila i zadanih ciljeva usmjerenih na promjenu socio-demografske strukture zaposlenika.

Treba međutim istaknuti da ovaj pristup ne isključuje mogućnost donošenja afirmativnih mjera. Naime, u mnogim se zemljama dva temeljna pristupa zapošljavanju manjina kombiniraju. Iako je donošenje afirmativnih mjera društvena reakcija i pokušaj ispravljanja povijesnih nepravdi prema pripadnicima pojedinih društvenih skupina, te se mjere primjenjuju i u suvremeno vrijeme. Komplementarno, ove dvije načelno razdvojene skupine mjera mogu pridonijeti, s jedne strane, povoljnijem položaju diskriminiranih društvenih skupina i, s druge, uspješnijem upravljanju različitošću u organizacijama.

\section{Pregled i analiza posebnih mjera zapošljavanja društvenih manjina u javnoj upravi u odabranim zemljama}

Donošenje posebnih mjera zapošljavanja pripadnika manjinskih skupina vjerojatno je, u odnosu prema drugim područjima upravljanja ljudskim potencijalima, tema koja izaziva najviše kontroverzija i podijeljenih mišljenja (Riccucci, 2005, str. 403). Prve takve mjere donose se u SAD-u, naročito u periodu 1965. - 1975. godine u okviru programa poznatijeg pod nazivom »afirmativna akcija«. U novije vrijeme sve popularniji postaje pristup upravljanja različitošću koji se od afirmativnog pristupa razlikuje u nekoliko osnovnih aspekata koji su prethodno prikazani. Počevši od osnovne intencije zakonodavca pa sve do faktičnih mjera koje se razlikuju po opsegu i učincima, različiti službenički sustavi pristupaju ovoj problematici u skladu s vlastitom tradicijom ${ }^{14}$ i specifičnim unutarnjim potrebama, a u

${ }^{14}$ Politike zapošljavanja u javnom sektoru moguće je razlikovati prema osnovnim obrascima socijalne politike (Esping-Andersen, 1990 prema Institut za javne financije, 2010, 
slučaju tranzicijskih zemalja i u okviru prilagodbe europskim i međunarodnim standardima.

Budući da u dostupnoj literaturi ne postoji klasifikacija metoda zapošljavanja pripadnika manjinskih skupina, izrađuje se pregled i provodi analiza odabranih modela zapošljavanja pripadnika društvenih manjina u javnoj upravi u različitim zemljama. Zemlje su odabrane utilitarnom logikom tako da se pazilo na vrstu i sadržaj posebnih mjera u zapošljavanju društvenih manjina kako bi na taj način bio obuhvaćen što širi krug različitih mjera. Analizom su obuhvaćene ove zemlje: Sjedinjene Američke Države - SAD, Nizozemska, Belgija, Norveška i Srbija.

Prvo su prikupljeni podaci kako bi se stekao početni uvid u raznolikost metoda zapošljavanja društvenih manjina, pri čemu je težište na analizi pravne regulacije, a ne na praksi i/ili dobrim praksama. Također, bilo je važno da o pojedinoj zemlji postoji razvijena literatura pa je stoga odabiru prethodio pregled dostupnih znanstvenih i stručnih radova koji se bave pitanjem zapošljavanja društvenih manjina u različitim zemljama. Za svaku odabranu zemlju utvrđuju se temeljne značajke službeničkih sustava, s posebnim naglaskom na postupak odabira i zapošljavanja društvenih manjina. Iznose se obilježja programa u okviru kojih se na različit način uređuje područje zapošljavanja manjinskih skupina. Takav pristup omogućuje donošenje zaključaka i klasifikaciju mjera kojima se pojedinim društvenim skupinama daje prednost pri zapošljavanju u javnoj upravi.

U nastavku su prikazana karakteristična obilježja zapošljavanja društvenih manjina u javnoj upravi u odabranim zemljama (tablica 1). Prvo se iznose glavna obilježja postupka zapošljavanja i položaja javnih službenika u svakoj zemlji, a potom temeljni pristup zapošljavanja društvenih manjina, ciljevi koji se žele postići takvim zapošljavanjem, stupanj centralizacije u odlučivanju o donošenju posebnih mjera zapošljavanja društvenih manjina, društvene skupine koje su takvim mjerama obuhvaćene i vrste posebnih mjera zapošljavanja.

str. 5): neoliberalni, u kojem je naglasak na učinkovitosti tržišta, restriktivnoj politici pomoći, s velikom društvenom stratifikacijom - primjer je Velika Britanija; socijaldemokratski, u kojem je stratifikacija mala, sustav javne socijalne skrbi veoma razvijen, država neposredno pruža zaštitu ili financijski pomaže ugroženim članovima društva te im nastoji poboljšati kvalitetu i omogućiti njihovo puno sudjelovanje na tržištu rada odnosno osiguranje za vrijeme nezaposlenosti - primjer su skandinavske zemlje; korporatistički, u kojem je visoka stratifikacija, a državna se intervencija ostvaruje reguliranjem tržišta ili financijskom pomoći - kao što se to čini u Njemačkoj i Francuskoj. 
Tablica 1. Karakteristična obiliežja zapošljavanja društvenib manjina (DM) u odabranim zemljama

\begin{tabular}{|c|c|c|c|c|c|}
\hline Obilježja & SAD & Nizozemska & Belgija & Norveška & Srbija \\
\hline $\begin{array}{l}\text { Zapošljavanje } \\
\text { i položaj } \\
\text { javnih } \\
\text { službenika }\end{array}$ & $\begin{array}{l}\text { - klasifika- } \\
\text { cija radnih } \\
\text { mjesta/ } \\
\text { platni } \\
\text { razredi } \\
\text { - slabljenje } \\
\text { položaja } \\
\text { pod utje- } \\
\text { cajem me- } \\
\text { nadžerskih } \\
\text { reformi }\end{array}$ & $\begin{array}{l}\text { - visok } \\
\text { stupanj } \\
\text { delegacije } \\
\text { personalne } \\
\text { politike } \\
\text { - autonomi- } \\
\text { ja rukovo- } \\
\text { ditelja } \\
\text { - poseban } \\
\text { pravni } \\
\text { položaj } \\
\text { službenika }\end{array}$ & $\begin{array}{l}\text { - visok stupanj } \\
\text { delegacije per- } \\
\text { sonalne politike } \\
\text { - autonomija } \\
\text { rukovoditelja } \\
\text { - poseban } \\
\text { pravni položaj } \\
\text { službenika, ali } \\
\text { uz trend sla- } \\
\text { bljenja položaja } \\
\text { (kontraktualno } \\
\text { zapošljavanje) }\end{array}$ & $\begin{array}{l}\text { - tradicionalna } \\
\text { (klasična) } \\
\text { javna uprava uz } \\
\text { postupnu de- } \\
\text { centralizaciju i } \\
\text { prijenos ovlasti } \\
\text { u provođenju } \\
\text { personalne } \\
\text { politike } \\
\text { - službenici } \\
\text { uglavnom } \\
\text { grade karijeru } \\
\text { u jednom mini- } \\
\text { starstvu/upravi }\end{array}$ & $\begin{array}{l}\text { - delegacija } \\
\text { personalne } \\
\text { politike } \\
\text { - autonomi- } \\
\text { ja rukovo- } \\
\text { ditelja } \\
\text { - poseban } \\
\text { pravni } \\
\text { položaj } \\
\text { službenika }\end{array}$ \\
\hline $\begin{array}{l}\text { Pristup } \\
\text { zapošljavanju } \\
\text { DM }\end{array}$ & $\begin{array}{l}\text { - afirmativni } \\
\text { - u novije } \\
\text { vrijeme } \\
\text { upravljanje } \\
\text { različito- } \\
\text { šću }\end{array}$ & $\begin{array}{l}\text { - afirmativni } \\
\text { - u novije } \\
\text { vrijeme } \\
\text { upravljanje } \\
\text { različito- } \\
\text { šću }\end{array}$ & $\begin{array}{l}\text { - mikstura: } \\
\text { jedinstvena } \\
\text { (vanjska) po- } \\
\text { litika jednakih } \\
\text { mogućnosti i } \\
\text { niz pojedinač- } \\
\text { nih (unutar- } \\
\text { njih) programa } \\
\text { upravljanja } \\
\text { različitošću }\end{array}$ & $\begin{array}{l}\text { - osim afirmativ- } \\
\text { nog pristupa u } \\
\text { zapošljavanju } \\
\text { žena, donose se } \\
\text { tek pojedinač- } \\
\text { ni programi } \\
\text { integracije } \\
\text { imigranata i } \\
\text { pilot projekti }\end{array}$ & - afirmativni \\
\hline Ciljevi & $\begin{array}{l}\text { - antidiskri- } \\
\text { minacija } \\
\text { - različitost; } \\
\text { multikul- } \\
\text { turalno } \\
\text { društvo }\end{array}$ & $\begin{aligned} & \text { - } \text { antidiskri- } \\
& \text { mi- } \\
& \text { nacija } \\
& \text { - različitost }\end{aligned}$ & $\begin{array}{l}\text { - jednake mo- } \\
\text { gućnosti } \\
\text { - antidiskrimina- } \\
\quad \text { cija } \\
\text { - različitost }\end{array}$ & $\begin{array}{l}\text { - rodna uravno- } \\
\text { teženost } \\
\text { - integracija } \\
\text { imigranata }\end{array}$ & $\begin{array}{l}\text { - antidiskri- } \\
\text { mi-nacija }\end{array}$ \\
\hline $\begin{array}{l}\text { Način odabira } \\
\text { mjera (cen- } \\
\text { tralizirano/ } \\
\text { decentral- } \\
\text { izi-rano } \\
\text { odlučivanje) }\end{array}$ & $\begin{array}{l}\text { - u prvo } \\
\text { vrijeme } \\
\text { centra- } \\
\text { lizirano/ } \\
\text { obvezuju- } \\
\text { će za niže } \\
\text { upravne } \\
\text { razine } \\
\text { - u novije } \\
\text { vrijeme } \\
\text { uglavnom } \\
\text { decentrali- } \\
\text { zirano }\end{array}$ & $\begin{array}{l}\text { - u prvo } \\
\text { vrijeme } \\
\text { centra- } \\
\text { lizirano/ } \\
\text { obvezuju- } \\
\text { će za niže } \\
\text { upravne } \\
\text { razine } \\
\text { - u novije } \\
\text { vrijeme } \\
\text { uglavnom } \\
\text { decentrali- } \\
\text { zirano }\end{array}$ & $\begin{array}{l}\text { - uglavnom de- } \\
\text { centralizirano }\end{array}$ & $\begin{array}{l}\text { - uglavnom } \\
\text { centralizirano }\end{array}$ & $\begin{array}{l}\text { - uglavnom } \\
\text { centralizi- } \\
\text { rano }\end{array}$ \\
\hline $\begin{array}{l}\text { Društvene } \\
\text { skupine }\end{array}$ & $\begin{array}{l}\text { - rasne i } \\
\text { nacionalne } \\
\text { manjine } \\
\text { - žene } \\
\text { - ratni } \\
\text { veterani }\end{array}$ & $\begin{array}{l}\text { - žene } \\
\text { - nacionalne } \\
\text { manjine } \\
\text { - osobe sta- } \\
\text { rije životne } \\
\text { dobi }\end{array}$ & $\begin{array}{l}\text { - nacionalne } \\
\text { manjine } \\
\text { - žene } \\
\text { - osobe s invali- } \\
\text { ditetom }\end{array}$ & $\begin{array}{l}\text { - žene } \\
\text { - osobe starije } \\
\text { životne dobi } \\
\text { - imigranti }\end{array}$ & $\begin{array}{l}\text { - rodne } \\
\text { manjine } \\
\text { - osobe s } \\
\text { invalidite- } \\
\text { tom } \\
\text { - osobe sta- } \\
\text { rije životne } \\
\text { dobi } \\
\text { - mladi }\end{array}$ \\
\hline
\end{tabular}


Vukojičić Tomić, T. (2017). Suvremeni pristupi i modeli zapošljavanja društvenih manjina...

\begin{tabular}{|c|c|c|c|c|c|}
\hline Mjere & $\begin{array}{c}\text { - prednost } \\
\text { pri zapo- } \\
\text { šljavanju } \\
\text { - ciljevi za- } \\
\text { pošljavanja }\end{array}$ & $\begin{array}{l}\text { - prednost } \\
\text { pri zapo- } \\
\text { šljavanju } \\
\text { - ciljevi za- } \\
\text { pošljavanja } \\
\text { - nagrade } \\
\text { rukovodi- } \\
\text { teljima } \\
\text { - financijske } \\
\text { potpore }\end{array}$ & $\begin{array}{l}\text { - ciljevi zapošlja- } \\
\text { vanja } \\
\text { - javne promidž- } \\
\text { bene kampanje } \\
\text { - rijetko i unapri- } \\
\text { jed rezervirana } \\
\text { radna mjesta } \\
\text { (na razini } \\
\text { regija) }\end{array}$ & $\begin{array}{l}\text { - tzv. rodne } \\
\text { kvote } \\
\text { - jasne mjere } \\
\text { zapošljavanja } \\
\text { imigranata još } \\
\text { se ne donose }\end{array}$ & $\begin{array}{l}\text { - ciljevi za- } \\
\text { pošljavanja } \\
\text { - kvote }\end{array}$ \\
\hline
\end{tabular}

Izvor: Autorica

U pogledu pristupa zapošljavanja društvenih manjina u javnoj upravi, među zemljama koje su odabrane za analizu mogu se uočiti neke sličnosti. One se očituju u shvaćanju manjinskog statusa pojedinih društvenih skupina kao društvenog problema i u izboru pristupa i instrumenata njegova rješavanja. U SAD-u se posebne mjere zapošljavanja pripadnika društvenih manjina donose kako bi se riješio društveni problem, odnosno nejednak položaj rasnih, nacionalnih i rodnih manjina (donekle i ratnih veterana) prihvaćen kao povijesna činjenica. Ta se situacija u određenoj mjeri može pripisati i tome da je riječ o visoko heterogenom, multikuturalnom društvu s povijesno jakim migracijskim priljevima. U pokušajima da riješi problem, država u prvom redu nastupa intervencionistički nastojeći pritom osigurati pojačano zapošljavanje pripadnika manjinskih skupina i njihovu razmjernu zastupljenost prema socio-demografskom sastavu stanovništva. U kasnijoj fazi, odlučivanje o donošenju najprikladnijih mjera zapošljavanja manjina prepušta se nižim upravnim razinama, dok vrh upravnog aparata donosi smjernice i donekle zadržava ovlasti nadzora nad provođenjem mjera. Slično je i u Nizozemskoj. Od početnog afirmativnog polazišta u zapošljavanju društvenih manjina, vidljiva je tendencija prihvaćanja pristupa upravljanja različitošću koji ističe drugačije vrijednosti i ciljeve, kao i tendencija prema decentralizaciji ovlasti u utvrđivanju najprikladnijih metoda njihova zapošljavanja. U Belgiji je reprezentativno zapošljavanje usmjereno na integraciju socijalno fragmentirane i jezično podijeljene $\mathrm{dr}$ žave (Bekke \& Van der Meer, 2000, str. 283), a visok stupanj autonomije triju regija dovodi do donošenja različitih programa i provođenja mjera zapošljavanja u skladu s unutarnjim potrebama i policy-orijentacijama. U Norveškoj je izražena tradicija socijalne države. ${ }^{15}$ Briga za socijalni status građana odražava se i na politike uključivanja onih skupina u društvu koje

15 Koprić et el. (2014, str. 42) kao glavna obilježja takvog modela države navode posvećenost ekonomskom i društvenom blagostanju građana, snažnu participaciju građana i transparentnost i otvorenost vlasti te aktivnu državu sa širokim ovlastima i opsegom dužnosti. 
su u nepovoljnijem položaju. Postoji jaka tradicija brige za položaj žena na tržištu rada, u nešto kasnijoj fazi i osoba starije životne dobi te osoba s invaliditetom, a u posljednje vrijeme i kulturološki različitih skupina zbog izraženih migracija stanovništva posljednjih desetljeća. U Srbiji se posebne mjere zapošljavanja donose za čitav niz manjinskih skupina pod utjecajem tradicije posebne pravne regulacije prednosti pri zapošljavanju u SFRJ, utvrđene kao mjera zaštite ili mjera posebne pomoći (Tintić, 1972, str. 105110). Te su mjere afirmativnog karaktera, orijentirane na rješavanje problema diskriminacije i unaprjeđenje položaja pojedinih društvenih skupina.

\section{Prijedlog klasifikacijskog modela zapošljavanja društvenih manjina}

Analiza odabranih službeničkih sustava omogućuje grupiranje i prijedlog klasifikacije posebnih mjera zapošljavanja manjina u javnoj upravi. Polazi se od dvaju temeljnih pristupa takvog zapošljavanja - afirmativnog i upravljanja različitošću. Na temelju razlikovanja tih dvaju pristupa u zapošljavanju manjina, koristeći se materijalom dobivenim analizom, predlaže se grupiranje posebnih mjera u dvije osnovne skupine: afirmativne metode i integrativne metode. Analiza različitih pristupa zapošljavanja društvenih manjina pokazuje da se pojedine mjere iz tih dviju skupina vrlo često primjenjuju komplementarno, jer se unatoč sve većoj popularnosti metoda koje idu za integracijom različitosti u organizaciji i dalje nastoji poboljšati nejednak položaj manjinskih društvenih skupina iz samog vrha upravnog sustava, i to propisivanjem mjera obveznog i/ili preferencijalnog zapošljavanja.

Afirmativne metode uvažavaju povijesne činjenice nejednakog postupanja prema pripadnicima određenih društvenih skupina. Polaze od problema diskriminacije i usmjerene su na ispravljanje posljedica prošle diskriminacije. Mjere koje se pritom poduzimaju uglavnom polaze od pravno utvrdenih dimenzija diskriminacije, a definiraju ih politička tijela kao odgovor na društveni problem. Na taj se način uspostavlja vertikalna odgovornost uprave za provedbu politički utvrđenih ciljeva zapošljavanja prema višim instancijama i horizontalna prema sudskoj instanciji koja obavlja kontrolu zakonitosti. Također, one idu za postizanjem razmjerne (reprezentativne) zastupljenosti pripadnika manjinskih društvenih skupina u upravnim organizacijama prema njihovoj zastupljenosti u društvenoj strukturi.

Najčešće je riječ o centralno utvrđenim mjerama preferencijalnog zapošljavanja među kojima se naročito izdvajaju: 
1. kvotno zapošljavanje

2. ciljevi zapošljavanja

3. unaprijed rezervirana radna mjesta.

Iako se kvotama i ciljevima zapošljavanja utvrđuju brojčano iskazani ciljevi, među njima postoji jedna vrlo značajna razlika. Kvote su čvrsto iskazani brojčani cilj zapošljavanja iza kojeg stoji mehanizam državnih sankcija i sudske zaštite. Iako su se prije vrlo često koristile kao instrument ispravljanja prošle diskriminacije i dovođenja u ravnopravan položaj pripadnika manjinskih skupina, u suvremeno se doba vrlo rijetko i oprezno koriste uglavnom da bi se zaštitio položaj osoba s invaliditetom na tržištu rada. ${ }^{16}$

Za razliku od kvota, ciljevi zapošljavanja predstavljaju fleksibilne brojčano iskazane ciljeve i indikatore željene razine zastupljenosti pripadnika manjinskih skupina (Riccucci, 2005, str. 413). Izvor imaju u propisima (vrlo često strategijama ili programima), ali uglavnom nisu obvezujućeg karaktera, već je riječ o centralno utvrđenim smjernicama kojima se želi poboljšati položaj manjinskih skupina. Utvrđivanje najboljeg načina postizanja ciljeva zapošljavanja je decentralizirano, jer se smatra da će same upravne organizacije pronaći najadekvatnije rješenje u skladu sa svojim unutarnjim potrebama. U oba se slučaja ciljevi uglavnom ostvaruju konzumiranjem prava na prednost pri zapošljavanju.

Još je jedan primjer afirmativne mjere koji se vrlo rijetko primjenjuje u suvremenim sustavima. Riječ je o unaprijed rezerviranim radnim mjestima (npr. čuvari, vratari) za pripadnike pojedinih manjinskih skupina kao što je slučaj sa zapošljavanjem ratnih veterana u SAD-u prije provedbe reforme državne uprave ili osoba s invaliditetom u flamanskoj regiji u Belgiji (Van de Walle et al., 2013, str. 83-84). S obzirom na to da je riječ o »čuvanju « određenog broja i tipa radnih mjesta za pojedine društvene skupine, mogu se smatrati i podvrstom kvotnog zapošljavanja.

Za razliku od afirmativnih metoda, integrativne metode ne polaze isključivo od problema diskriminacije, već pomiču interes prema većoj uspješnosti organizacija putem različitosti. Usmjerene su na postizanje različitosti u strukturi ljudskih potencijala u skladu sa socio-demografskom složenošću društva, a ne na reprezentativnu zastupljenost društvenih skupina koje su formalnopravno određene kao manjinske skupine zbog svog nepovoljnijeg položaja na tržištu rada. Utemeljenje im je individualnost pojedinaca i njihova međusobna različitost po širokim osnovama, prihvaćanje i priznanje vačka i Srbija.

${ }^{16}$ Koriste ih npr. Austrija, Hrvatska, Njemačka, Poljska, Rumunjska, Slovenija, Slo- 
individualne različitosti kako bi se maksimirali potencijali svih zaposlenika. Te metode ne idu toliko za afirmacijom položaja pravno priznatih diskriminiranih skupina pojedinaca, već njihovom integracijom u šire radno okruženje stvaranjem pogodnih uvjeta kroz promjenu vrijednosti, organizacijske kulture i upravljanja ljudskim potencijalima. Usmjerene su na dugoročne promjene, a ne isključivo na korigiranje strukture zaposlenika, čime se rješava društveni problem nejednakosti. Kao i afirmativne metode, polaze od različitosti kao sve izraženijeg izazova suvremenih društava, ali su primarno orijentirane na privlačenje i zadržavanje različitih ljudskih potencijala kao strateškom cilju koji inkorporira društveno-simboličke i političko-legitimacijske ciljeve, ali i imperativ organizacijske uspješnosti.

Odluke o mjerama koje je potrebno poduzeti uglavnom su decentralizirane na niže upravne razine. Nije međutim rijetkost da središnja tijela donose smjernice u okviru integralnih programa ili čak i konkretne mjere koje se odnose na cjelokupni upravni sustav. Kad je riječ o smjernicama za integraciju različitosti u organizacijama (npr. strateški programi), pojedinim upravnim organizacijama prepuštena je odluka o donošenju najprikladnijih mjera za ostvarenje društvene potrebe i cilja. Konkretnim mjerama središnjih tijela, kao što su nacionalni zavodi za zapošljavanje, potiče se zapošljavanje pripadnika pojedinih društvenih skupina koje su slabije zastupljene u korpusu zaposlenih osoba kako bi on bolje odrazio socio-demografski sastav stanovništva. Najčešće mjere koje se pritom koriste jesu:

1. poticanje zapošljavanja

2. promidžbene kampanje

3. ciljano oglašavanje.

Poticanje zapošljavanja obuhvaća različite oblike financijske potpore organizacijama za zapošljavanje pripadnika pojedinih društvenih skupina, nagrade rukovoditeljima koji uspješno ispunjavaju planove zapošljavanja te programe privremenog zapošljavanja pojedinaca koji pripadaju različitim društvenim skupinama, recimo mladih osoba, i/ili njihovo stručno osposobljavanje odnosno usavršavanje kako bi im se poboljšao položaj na tržištu rada. ${ }^{17}$ Riječ je o aktivnim mjerama poticanja zapošljavanja širokog

17 Razlažući sustav poticajnih mjera za zapošljavanje i održavanje zaposlenosti osoba s invaliditetom, Žunić (2001, str. 195-197) govori o nekoliko skupina poticajnih mjera ovisno o njihovu sadržaju i obliku: materijalno financijske (porezne olakšice i stimulacije, financijska ulaganja i potpore iz proračuna, fondova, fundacija i sl.), tebničke (nabava strojeva i opreme, uvođenje novih tehnologija i tehničkih sredstava i sl.), stručne (osnivanje i organiziranje različitih stručnih institucija za profesionalnu rehabilitaciju) i savjetodavne naravi (pomoć stručnog voditelja ili osobna pomoć u radu). Kako navodi, cilj je takvih mjera zapošljavanje i očuvanje zaposlenosti, samozapošljavanje, a rjeđe i zapošljavanje pod posebnim uvjetima. 
kruga različitih društvenih skupina koje trebaju unaprijediti nepovoljniji položaj osoba različitih karakteristika i poticati različitosti, a objedinjuje demokratsko-legitimacijska nastojanja da se izjednači položaj svih društvenih skupina i korištenje potencijala različitosti za uspješnije postizanje organizacijskih ciljeva.

Promidžbene kampanje provode se uglavnom putem medija, i tada je riječ o javnim promidžbenim kampanjama, ali i unutar samih upravnih organizacija (npr. isticanje plakata ili promidžbenih letaka na vidljivim mjestima u upravnim organizacijama). Vrlo je važno da budu popraćene informiranjem i programima obrazovanja za različitost upravnog osoblja, a naročito vodstva u upravi, koje treba potaknuti na stvaranje inkluzivne kulture u organizaciji. Promidžbene kampanje imaju dva osnovna cilja. Prvi ima vrijednosnu komponentu i odnosi se na ukupnu javnost čije se razmišljanje i percepcija želi usmjeriti k prihvaćanju različitosti i jednakih mogućnosti kao temeljnih vrijednosti. Njima se također želi unaprijediti imidž javne uprave u javnosti. One isto tako djeluju ciljano prema određenim društvenim skupinama kako bi ih se potaknulo na zapošljavanje u javnoj upravi.

Ciljanim oglašavanjem upravna organizacija izravno se obraća određenim društvenim skupinama koje su nedovoljno zastupljene ili čak podzastupljene u organizaciji s obzirom na socio-demografski sastav stanovništva. Najčešće se oslanja na programske ciljeve zapošljavanja koje organizacije razvijaju u okviru nacionalnih strategija i uglavnom se provodi u lokalnim javnim službama. Ciljano oglašavanje proizlazi iz ideje da sastav upravnog osoblja treba odražavati različitost korisnika javnih usluga ne samo da bi se poboljšao nejednak položaj pojedinih društvenih skupina već i kako bi se unaprijedila kvaliteta javnih usluga u heterogenim lokalnim zajednicama. Primjer za to je ciljano oglašavanje posla u lokalnim zdravstvenim službama (Primary Care Trust) u Velikoj Britaniji u kojima se oglas za radno mjesto prevodi na različite jezike, objavljuje na službenim internetskim stranicama, šalje udrugama građana i lokalnim inicijativama te oglašava u manjinskim tiskovinama kako bi se privukao što veći broj kandidata (Progress, 2009, str. 58).

Osnovna obilježja i razlike između metoda zapošljavanja društvenih manjina u javnoj upravi s obzirom na nekoliko kriterija (svrhu, vrijednosno usmjerenje, stupanj centralizacije u odlučivanju, vrstu mjera, očekivane rezultate i način mjerenja uspjeha) prikazani su u tablici 2.

Iako je ova klasifikacija prvenstveno usmjerena na sustav poticajnih mjera za osobe s invaliditetom, prikladna je i za dobivanje uvida u širinu mjera koje mogu biti poduzete da bi se potaknulo i očuvalo zapošljavanje svih društvenih manjina u nekom društvu. 
Tablica 2. Temeljna obilježja i razlike izmedu afirmativnih $i$ integrativnih metoda u zapošljavanju društvenib manjina

\begin{tabular}{|l|l|l|}
\hline \multicolumn{1}{|c|}{ Afirmativne metode } & \multicolumn{1}{|c|}{ Integrativne metode } \\
\hline Svrha & Ispravljanje posljedica diskriminacije & $\begin{array}{l}\text { Postizanje različitosti i integracija u } \\
\text { radno okruženje; doprinos uspješnosti u } \\
\text { ostvarenju organizacijskih ciljeva }\end{array}$ \\
\hline $\begin{array}{l}\text { Vrijednosno } \\
\text { usmjerenje }\end{array}$ & Pravne i političke vrijednosti & $\begin{array}{l}\text { Uz pravne i političke vrijednosti ističu } \\
\text { se ekonomske vrijednosti }\end{array}$ \\
\hline $\begin{array}{l}\text { Stupanj } \\
\text { centralizacije u } \\
\text { odlučivanju }\end{array}$ & Uglavnom centralizirano & Uglavnom decentralizirano \\
\hline $\begin{array}{l}\text { Vrste mjera } \\
\text { Brojčano iskazani ciljevi (kvote, ciljevi } \\
\text { zapošljavanja, rezervirana radna mjesta) }\end{array}$ & $\begin{array}{l}\text { Poticanje zapošljavanja (financijske pot- } \\
\text { pore i nagrade, promidžbene kampanje, } \\
\text { ciljano oglašavanje) }\end{array}$ \\
\hline $\begin{array}{l}\text { Očekivani } \\
\text { rezultati }\end{array}$ & $\begin{array}{l}\text { Zastupljenost u organizaciji razmjerna } \\
\text { zastupljenosti u stanovništvu }\end{array}$ & $\begin{array}{l}\text { Organizacija kao »slika« društva; bolja } \\
\text { kvaliteta javnih usluga }\end{array}$ \\
\hline $\begin{array}{l}\text { Mjerenje } \\
\text { uspjeha }\end{array}$ & $\begin{array}{l}\text { Usklađenost strukture upravnog osoblja } \\
\text { s predviđenim ciljevima; vertikalna i } \\
\text { horizontalna odgovornost (moguća i } \\
\text { sudska kontrola) }\end{array}$ & $\begin{array}{l}\text { Usklađenost strukture upravnog osoblja } \\
\text { sa strukturom stanovništva; promjena } \\
\text { kulture i stavova; viša razina kvalitete } \\
\text { javnih usluga }\end{array}$ \\
\hline
\end{tabular}

Izvor: Autorica.

\section{Zaključak}

Povećanje socio-demografske i drugih oblika složenosti suvremenih zajednica istovremeno je problem i izazov. Problemi nastaju kad se, po raznim dimenzijama različitosti, pojedinci i skupine nađu u nejednakom ili nepovoljnijem položaju od ostatka stanovništva. Razvija se čitav spektar definicija koje takav nejednaki položaj nazivaju manjinskim, jer je riječ o društvenim skupinama koje se po svojim kulturološkim i fizičkim obilježjima razlikuju od drugih skupina u društvu i koje nisu u dominantnom položaju. S druge strane, građani se pojavljuju u ulozi interesenata koji nastoje svoje interese izraziti i zadovoljiti, što rezultira širenjem kruga legitimnih društvenih interesa onda kad se ti interesi smatraju prihvatljivima i kad društvo omogućuje ostvarivanje tih interesa. Sinergijsko djelovanje tih dvaju procesa dovodi do donošenja kolektivno obvezujućih odluka kojima se nastoji riješiti društveni problem nejednakosti. One se odražavaju i na javnu upravu tako da uzrokuju objektivne promjene u strukturi upravnog osoblja, a ujedno postavljaju zahtjeve za novim pristupima u postupku odabira i zapošljavanja javnih službenika. U takvoj situaciji i na tim polazištima poduzimaju se prve mjere kojima se pojedine manjinske skupine 
želi dovesti u povoljniji položaj u pogledu izjednačavanja mogućnosti u zapošljavanju. Riječ je o afirmativnom pristupu i, u skladu s njim, metodama afirmacije koje polaze od problema diskriminacije i usmjerene su na ispravljanje posljedica prošle diskriminacije.

U novije vrijeme opisani procesi počinju se promatrati i tretirati kao izazov u upravljanju suvremenim organizacijama. Razvija se integrirani pristup upravljanja različitošću koji istodobno uključuje društveno-simboličku komponentu na kojoj počiva afirmativni pristup i komponentu organizacijske uspješnosti. Izazov se očituje u tome da privlačenje i zadržavanje različitih ljudskih potencijala, uz stvaranje organizacijske kulture koja prihvaća i njeguje različitosti, može doprinijeti postizanju organizacijskih ciljeva i ukupnoj uspješnosti organizacije.

U okviru tih dvaju temeljnih pristupa razvijaju se metode i mjere koje se u radu klasificiraju na metode afirmacije i metode integracije. Razlikuju se u nekoliko aspekata, od načina njihova određivanja i mjesta u upravnom sustavu na kojem se o njima odlučuje, preko instrumenata nadzora nad njihovim provođenjem, dubine i intenziteta promjena koje izazivaju pa sve do načina provjere uspjeha u njihovu provođenju. Iako se nedvojbeno razlikuju, vrlo se često koriste kao komplementarne metode kako bi suvremene organizacije što bolje u sebi odrazile složenost relevantne okoline.

\section{Literatura}

Bahtijarević-Šiber, F. (2014). Strateški menadžment ljudskih potencijala: Suvremeni trendovi $i$ izazovi. Zagreb, Hrvatska: Školska knjiga.

Bekke, H. A. G. M \& Van der Meer, F. M. (2000). West European civil service systems: variations and similarities. U H. A. G. M. Bekke \& F. M. van der Meer (eds.), Civil service systems in Western Europe (str. 275-291). Cheltenham, UK: Edward Elgar Publishing Limited.

Čačić-Kumpes, J. (2004). Politike reguliranja kulturne i etničke različitosti: o pojmovima i njihovoj upotrebi. Migracijske i etničke teme, 20(2-3), 143-159.

Dessler, G. (2005). Human resource management. Upper Saddle River, New York, USA: Pearson Prentice Hall.

Frederickson, H. G. (2010). Social equity and public administration: Origins, developments and applications. Armonk, New York, USA: M. E. Sharpe.

Gardenswartz \& Rowe (2003). Diverse teams at work: dimensions of diversity. Preuzeto s: http://www.gardenswartzrowe.com/why-g-r.

Guy, M. E. \& Newman M. A. (2005). Valuing diversity: the changing workplace. U: S. E. Condrey (eds.), Handbook of buman resource management in government (str. 143-164). San Francisco, USA: Jossey-Bass. 
Hays, S. W. \& Sowa J. E. (2005). Staffing the bureaucracy: Employee recruitment and selection. U: S. E. Condrey (eds.) Handbook of buman resource management in government (str. 97-125). San Francisco, USA: Jossey-Bass.

Henderson, G. \& Olasiji T. (1995). Migrants, immigrants, and slaves: racial and ethnic groups in America. Lanham, USA: University Press of America, Inc.

Institut za javne financije (2010). Analiza sustava zaposlenib u brvatskom javnom sektoru. Zagreb, Hrvatska: Institut za javne financije.

Koprić, I. (1999). Struktura i komuniciranje u upravnim organizacijama. Zagreb, Hrvatska: Pravni fakultet Sveučilišta u Zagrebu.

Koprić, I. (2009). Attracting and retaining the best people in civil service. Sarajevo, Bosna i Hercegovina: UNDP Bosna i Hercegovina.

Koprić, I., Marčetić, G., Musa, A., Đulabić, V. \& Lalić Novak, G. (2014). Upravna znanost: javna uprava u suvremenom europskom kontekstu. Zagreb, Hrvatska: Pravni fakultet Sveučilišta u Zagrebu.

Marčetić, G. (2007). Upravljanje ljudskim potencijalima u javnoj upravi. Zagreb, Hrvatska: Društveno veleučilište u Zagrebu.

Meier Kenneth, J., Wrinkle, R. D. \& Polinard, J. L. (1999). Representative bureaucracy and distributional equity: addressing the hard question. The Journal of Politics, 61(4), 1025-1039.

Mesić, M. (2006). Multikulturalizam: društveni i teorijski izazovi. Zagreb, Hrvatska: Školska knjiga.

Millmore, M., Lewis, P., Saunders, M., Thornhill, A. \& Morrow, T. (2007). Strategic buman resource management: contemporary issues. Harlow, USA: Prentice Hall Financial Times.

Peters, B. G. (2013). Representative bureaucracy in the United States. U: P. von Maravić, B. G. Peters \& E. Schröter (eds.), Representative bureaucracy in action: country profiles from the Americas, Europe, Africa and Asia (str. 21-35). Cheltenham, UK: Edward Elgar Publishing Limited.

Peters, B. G., Schröter E. \& Von Maravić P. (2013). Representative bureaucracy: concept, driving forces, strategies. U: P. von Maravić, B. G. Peters \& E. Schröter (eds.), Representative bureaucracy in action: Country profiles from the Americas, Europe, Africa and Asia (str. 1-21). Cheltenham, UK: Edward Elgar Publishing Limited.

Potočnjak, Ž. \& Grgić A. (2014a). Osnovni pojmovi i koncepcije o zabrani diskriminacije u radnom pravu. U: Ž. Potočnjak, I. Grgurev \& A. Grgić (ur.), Perspektive antidiskriminacijskog prava (str. 1-49). Zagreb, Hrvatska: Pravni fakultet Sveučilišta u Zagrebu.

Potočnjak, Ž. \& Grgić, A. (2014b). Izuzeci i opravdanja kod zabrane diskriminacije. U: Ž. Potočnjak, I. Grgurev \& A. Grgić (ur.), Perspektive antidiskriminacijskog prava (str. 153-199). Zagreb, Hrvatska: Pravni fakultet Sveučilišta u Zagrebu.

Progress - European Commission (2009). International perspectives on positive action maeasures: a comparative analysis in the European Union, Canada, the United States and South Africa. Luxembourg: Office for Official Publications of the European Communities. 
Pusić, E. (2005). Upravne organizacije: interakcija - struktura - interes. Zagreb, Hrvatska: Društveno veleučilište u Zagrebu.

Riccucci, N. M. (2005). A practical guide to affirmative action. U: S. E. Condrey (eds.) Handbook of buman resource management in government (str. 403-423). San Francisco, SAD: Jossey-Bass.

Selden, C. S. (1997). The promise of representative bureaucracy: diversity and responsiveness in a government agency. Armonk, SAD: M. E. Sharpe.

Stahl, O. G. (1956). Public Personnel Administration. New York, SAD: Harper \& Brothers.

Tintić, N. (1972). Radno i socijalno pravo: radni odnosi II. Zagreb, Hrvatska: Narodne novine.

Van de Walle, S., Groeneveld, S. \& Vandenbussche, L. (2013). Representative bureaucracy in Belgium: power sharing or diversity? U: P. von Maravić, B. G. Peters \& E. Schröter (eds.), Representative bureaucracy in action: country profiles from the Americas, Europe, Africa and Asia (str. 69-87). Cheltenham, UK: Edward Elgar Publishing Limited.

Van Gool, B. (2015). From Plutocracy to diversity: the (de)construction of represenative bureaucracy theory. U: B. G. Peters, P. von Maravić \& E. Schröter (eds.), Politics of representative bureaucracy: Power, legitimacy and performance (str. 161-179). Cheltenham, UK: Edward Elgar Publishing Limited.

Žunić, Z. (2001). Profesionalnom rehabilitacijom u 21. stoljeće. Zagreb, Hrvatska: Državni zavod za zaštitu obitelji, materinstva i mladeži. 


\section{RECRUITING MINORITIES IN PUBLIC ADMINISTRATION: CONTEMPORARY APPROACHES AND MODELS}

\section{Summary}

Recruiting minority group members for public administration positions requires a specific approach to the selection and employment of civil servants. As modern societies undergo socio-demographic changes and grow increasingly complex, this brings about the development of various policies and measures that attempt to reflect social diversity in public administration biring practices. In addition, special models of recruiting minority group members have been developed within the scope of international anti-discrimination legislation since the 1960s. It is by implementing special biring policies regarding minority groups in public administration positions that discriminatory practices are sought to be avoided or reduced and diversity is sought to be integrated into the organisation. Opting for a particular biring model depends on the reasons for this decision as well as the intended goal. Attention should also be paid to the general characteristics of the tradition of public administration in a particular society. Because there is no universally accepted definition in the available literature, nor is there a universally accepted classification or nomenclature that would encompass all aspects of such recruiting models, the paper investigates the possibility of integrating practical approaches. When it comes to minority groups, existing biring models are divided into two basic approaches - the affirmative approach and the diversity management approach - based on the differences in their origins, their intended goals, the method of measuring their success rate, and the extent to which decision-making is centralised. Building on these two basic approaches to recruiting minority group members, various hiring policies in selected countries are analysed. The analysis serves to develop a proposal for the classification of special policies of recruiting minority group members for public administration positions into affirmative methods and integrative methods, which are often combined in practice.

Keywords: public administration, minority groups, recruiting minority group members, affirmative approach, diversity management 